\title{
Kerajaan Sekadau Sebagai Sumber Belajar Sejarah Dalam Materi Kerajaan Islam di Indonesia
}

\author{
\begin{tabular}{cc} 
SUSI SUSANTI \\
\hline STKIP PGRI Pontianak \\
Susi-2184@yahoo.com
\end{tabular}
}

\begin{abstract}
Abstrak
Penelitian ini bertujuan mengetahui perencanaan dan pelaksanaan guru sejarah dalam menyampaikan Kerajaan Sekadau sebagai sumber belajar sejarah dalam materi Kerajaan Islam di Indonesia pada siswa kelas XI SMA Negeri 1 Nanga Taman. Penelitian ini menggunakan metode deskriptif dengan pengumpulan data melalui observasi langsung, komunikasi langsung dan dokumentasi. Pengambilan sampel dilakukan dengan purposive dan snowball sampling. Analisis data meliputi: pengumpulan data, reduksi data, penyajian data, dan kesimpulan. Hasil penelitian menunjukan: (1) Perencanaan telah dilakukan dengan baik, nampak pada kemampuan guru dalam mempersiapkan RPP dan Silabus serta pemanfaatan bahan pembelajaran buku sejarah Kerajaan Sekadau dan buku lain yang relevan. (2) Pelaksanaan telah berjalan baik, nampak dari respon siswa terhadap penggunaan model pembelajaran klasikal yang bertujuan mempermudah pemahaman dan menciptakan suasana pembelajaran yang kondusif; siswa aktif dalam pembelajaran; siswa diarahkan berpikir kronologis dan memilki pengetahuan masa lampau, siap menghadapi masa depan, dan melestarikan serta mewariskan peristiwa masa lampau yang bermakna bagi generasi seterusnya.
\end{abstract}

Kata Kunci: Kerajaan Sekadau, Sumber Belajar.

\begin{abstract}
This research aims to know the lesson planning and implementing of history teachers in explaining the Sekadau Kingdom as learning resources in the material of the Islamic empire in Indonesia for grade XI students of SMAN 1 Nanga Taman. The research utilizes descriptive method. The data collection techniques include direct observations, direct communications and documentations. The sampling was performed by using purposive and snowball sampling technique. The data analysis includes: data collection, data reduction, data presentation, and conclusion. The research findings show that: (1) the lesson planning has been done well. This can be seen from the ability of teachers to prepare lesson plans and syllabus as well as learning materials by utilizing Sekadau kingdom history books and other relevant books. (2) The lesson implementation has run well. This is indicated by: the students gave response to the use of classical learning model that aims to facilitate the understanding and create a conducive atmosphere for learning; students are active in learning; students are directed to think chronologically and have the knowledge of the past, students are ready to face the future, and preserve as well as pass on the meaningful past events to the next generation.
\end{abstract}

Keywords: Sekadau Kingdom, Learning Sources. 


\section{PENDAHULUAN}

Peningkatan kualitas pendidikan merupakan suatu proses yang dilaksanakan secara dinamis dan berkesinambungan dalam upaya pencapaian tujuan pendidikan secara efektif dan efisien. Program peningkatan kualitas pendidikan adalah tercapainya tujuan pendidikan nasional secara substantif, yang diwujudkan dalam kompetensi yang utuh pada diri peserta didik, meliputi kompetensi akademik atau modal intelektual, kompetensi sosial atau modal sosial dan kompetensi moral atau modal moral (Zamroni, lewat Aman, 2011: 3).

Lingkungan sekolah merupakan salah satu tempat atau wahana yang paling umum digunakan sebagai tempat untuk membentuk manusia yang sehat jasmani dan rohani serta membentuk manusia Indonesia yang berlandaskan pada pancasila, yang mempunyai modal intelektual, sosial, dan moral. Lingkungan sekolah merupakan sarana yang dianggap paling tepat karena dapat menumbuhkan minat dan merangsang para siswa untuk berbuat dan membuktikan hasil pembelajaran yang telah dicapai, khususnya pada bidang ilmu pengetahuan dan ilmu teknologi. Dalam upaya mewujudkan pengajaran yang baik dan mendidik, seorang guru sangat berperan karena setiap keputusan dan tindakan seorang guru dapat membawa hal yang positif terhadap para siswa.

Pembelajaran sejarah merupakan pelajaran sosial yang penting bagi siswa untuk kehidupannya yang akan datang. Bermula dari sejarah kehidupan manusia yang pastinya sangat berharga dan bernilai positif di mana manusia memiliki sejarahnya masing-masing dari kecil hingga akhir hayatnya. Sejarah diartikan sebagai peristiwa masa lalu yang tidak mungkin terulang sama persis diwaktu yang akan datang. Sejarah memberikan arti yang sangat baik bagi kehidupan. Tidak ada manusia yang tidak memiliki sejarah, termasuk para siswa. Dengan pembelajaran sejarah diharapkan siswa dapat mempelajari kehidupan sebelumnya agar mereka tidak melupakan darimana mereka berasal serta dapat mengambil hikmah dari segala peris- tiwa yang pernah terjadi.

Menurut Hugiono dan Poerwantana (lewat Isjoni, 2007:18), sejarah adalah gambaran tentang peristiwa-peristiwa masa lampau yang dialami manusia, disusun secara ilmiah meliputi urutan waktu, diberi tafsiran dan analisis kritis sehingga mudah dimengerti dan dipahami. Definisi ini lebih tegas dikemukakan Sjamsudin dan Ismaun (lewat Isjoni, 2007:18) bahwa sejarah berarti cerita atau kejadian yang benar-benar sudah terjadi atau berlangsung pada waktu yang lalu, yang telah diteliti oleh penulis sejarah dari masa ke masa.

Berbagai tempat pasti memiliki sejarahnya masing-masing. Tempat-tempat bersejarah tersebut dapat dijadikan sumber belajar yang nyata bagi siswa. Selain mengajar dan mendidik seorang guru juga harus dapat memilih bahan ajaran dan sumber belajar yang dapat mengembangkan cara berpikir serta menambah pengetahuan dan membentuk kepribadian siswa. Keberhasilan pembelajaran sangat bergantung pada penggunaan sumber pembelajaran yang dipilih. Jika sumber-sumber pembelajaran dipilih dan disiapkan dengan tepat maka tujuan pembelajaran akan terpenuhi. Sumber belajar sangat diharapkan dapat menunjang dan mendukung kegiatan belajar mengajar di sekolah, dan pemanfaatan situs bersejarah Kerajaan Sekadau diharapkan dapat mendukung proses belajar mengajar serta upaya melestarikan kebudayaan Kabupaten Sekadau yang ada melalui siswa di sekolah.

Asal usul penduduk Sekadau berasal dari pecahan rombongan Daranante yang mencari suaminya yang bernama Babai Cinga. Diantara rombongan Daranante ada rombongan yang terpisah yang dipimpin oleh Singa Patih Bardat dan Patih Bangi. Rombongan ini lalu menyusuri sungai Kapuas hingga ke hulu. Rombongan yang dipimpin oleh Singa Patih Bardat telah berkembang biak dan menurunkan Suku Kematu, Suku Benawas, Sekadau dan Melawang. Rombongan yang dipimpin oleh Patih Bangi, meneruskan perjalanannya sampai kedaerah Belitang sekarang. Didaerah inilah berkembangnya keturunan Dayak Melawang yang menurunkan 
Raja-Raja Sekadau (Usman, 2011:123).

Menurut J.U. Lontaan dalam buku Sejarah Hukum Adat dan Adat Istiadat Kalimantan Barat yang diterbitkan oleh Pemerintah Tingkat I Kalimantan Barat pada tahun 1975 (Saad, 2009:5), nama "Sekadau" diambil dari sejenis pohon kayu yang banyak tumbuh di muara sungai yang sekarang disebut sungai Sekadau. Oleh penduduk, pohon kayu ini disebut "Batang Adau".

Masuknya agama Islam sendiri terjadi ketika masa kepemimpinan Sultan Anom yaitu anak dari Pangeran Suma, Raja Sekadau sebelumnya. Pada awal berdiri Kerajaan Sekadau, masyarakat setempat telah memiliki kepercayaan sebagaimana penduduk zaman dulu yang telah mempercayai adanya banyak roh-roh yang mengawasi setiap perbuatan manusia, sehingga mereka percaya akan benda-benda ghaib dan roh-roh mahluk halus. Begitu juga dengan masyarakat di Kerajaan Sekadau yang percaya akan rohroh halus atau yang dinamakan kepercayaan Animisme. Seiring dengan masuknya agama Islam ke daerah ini suku-suku dayak yang masuk kedalam agama Islam kemudian mengklaim dirinya sebagai Suku Melayu yang biasa disebut dengan Dayak Senganan ini pun mulai mempunyai banyak keturunan di daerah ini.

Minimnya pengetahuan siswa tentang berbagai jenis kebudayaan yang ada di daerahnya membuat peneliti tertarik untuk melakukan penelitian ini. Dengan memanfaatkan berbagai sejarah kebudayan yang ada di sekeliling siswa sebagai sumber belajar diharapkan dapat menjadi cara guru dalam memperkenalkan sejarah kebudayaan itu sendiri. Dengan begitu siswa akan mengenali daerah tempat tinggalnya melalui pembelajaran yang berlangsung di sekolah.

Upaya pemanfaatan Kerajaan Sekadau sebagai sumber belajar pada siswa Sekolah Menengah Atas Negeri 2 Sekadau Kabupaten Sekadau oleh guru merupakan suatu upaya pelestarian Sejarah Lokal serta menumbuhkan rasa kecintaan siswa terhadap berbagai situs sejarah serta kebudayaan daerah dan peninggalan-peninggalan sejarah Kerajaan Sekadau. Selain itu juga bisa menjadi sumber ilmu pengetahuan para siswa untuk mengenal secara dalam tentang sejarah Kerajaan Sekadau. Pentingnya pelestarian Sejarah Lokal dan peninggalan-peninggalannya harus ditanamkan pada generasi muda sejak dini agar kebudayaan yang ada tidak hilang begitu saja oleh zaman yang semakin modern. Hal ini juga dapat menumbuhkan rasa cinta tanah air yang tinggi yang selaras dengan pembangunan yang seutuhnya.

Peninggalan-peninggalan seperti yang ada disuatu wilayah atau suatu daerah khususnya Kabupaten Sekadau berupa Keraton, Masjid, Meriam dan Makam-makam Raja dapat digunakan sebagai sumber belajar pada siswa Sekolah Menengah Atas Negeri 2 Sekadau Kabupaten Sekadau. Karena peninggalan tersebut banyak menyimpan kisah-kisah Kerajaan Sekadau. Maka dari itu pengetahuan siswa tentang sejarah Kerajaan Sekadau sangat perlu dipelajari karena dapat membuat siswa lebih memahami tentang sejarah Kerajaan yang ada di daerahnya serta mengetahui peninggalan-peninggalan Kerajaan Sekadau. Karena hal-hal tersebut dapat meningkatkan motivasi serta minat belajar siswa dalam melaksanakan pembelajaran sejarah.

Perkembangan zaman yang modern semakin menjauhkan siswa dari kebudayaan yang ada khususnya tentang pentingnya pengetahuan mengenai masuknya Islam ke Indonesia, melalui benda-benda peninggalan sejarah. Kemudian perkembangan teknologi yang semakin maju dan canggih membuat siswa malas dan mulai meninggalkan sejarah, karena mungkin pelajaran sejarah merupakan pelajaran mengenai masa lalu dan dianggap ketinggalan zaman dan membosankan. Apalagi jika guru tersebut hanya bercerita tanpa bukti yang nyata oleh sebab itu maka dalam hal ini peneliti memanfaatkan Kerajaan Sekadau sebagai sumber belajar melalui benda-benda peninggalan zaman dulu.

Kerajaan Sekadau dapat diintegrasikan dalam pembelajaran sejarah dengan materi pada Standar Kompetensi menganalisis perjalanan bangsa Indonesia pada masa negara-negara tradisional dan pada Kompetensi Dasar menganalisis pengaruh perkemban- 
gan agama dan kebudayaan Islam terhadap masyarakat di berbagai daerah di Indonesia. Dengan begitu guru dapat menghubungkan Kerajaan Sekadau tersebut dalam materi masuk dan berkembangnya agama Islam di Indonesia pada pembelajaran sejarah sebagai sumber belajar siswa di kelas XI.

Pada materi masuk dan berkembangnya agama Islam di Indonesia dijelaskan bagaimana teori masuknya Islam ke Nusantara, terbentuknya Kerajaan Islam di Indonesia, sistem kekuasaan dan hukum pada masa Islam awal, dan perubahan sistem sosial-budaya masyarakat yang dipengaruhi Islam akan dikaitkan dengan situs Kerajaan Sekadau sebagai sumber belajar pada masa masuknya agama Islam ke berbagai daerah di Indonesia khususnya daerah Sekadau. Berdasarkan latar belakang di atas maka dalam pembatasan masalah atau fokus dalam penelitian ini secara umum adalah "Bagaimanakah Kerajaan Sekadau Sebagai Sumber Belajar Sejarah Pada Siswa Kelas XI Sekolah Menengah Atas Negeri 2 Sekadau Kabupaten Sekadau".

Agar penelitian ini dapat dilaksanakan secara terarah dan terperinci maka dibuatlah sub-sub masalah sebagai berikut:

1. Bagaimanakah proses pembelajaran sejarah pada materi masuk dan berkembangnya agama Islam di Indonesia pada siswa kelas XI Sekolah Menengah Atas Negeri 2 Sekadau Kabupaten Sekadau?

2. Bagaimanakah penggunaan Kerajaan Sekadau oleh guru sejarah sebagai sumber belajar pada siswa kelas XI Sekolah Menengah Atas Negeri 2 Sekadau Kabupaten Sekadau?

3. Apakah Kerajaan Sekadau dapat dijadikan sumber belajar sejarah pada materi masuk dan berkembangnya agama Islam di Indonesia pada siswa kelas XI Sekolah Menengah Atas Negeri 2 Sekadau Kabupaten Sekadau?

\section{METODE}

Metode penelitian yang digunakan oleh peneliti adalah metode penelitian deskriptif. Metode deskriptif dapat diartikan pene- litian yang berkaitan dengan pengumpulan data untuk memberikan gambaran atau penegasan suatu konsep atau gejala, juga menjawab pertanyaan-pertanyaan sehubungan dengan subjek penelitian pada saat ini (Darmadi, 2011:7). Selain itu menurut Mason dan Bramble (1989:35) "Descriptive research is also conducted to advance the broader aims of science. In this context, it is usually perfomed to devolop knowledge on which the problems and explanations of subsequent research will be based". Artinya penelitian deskriptif juga mampu mendorong peningkatan kemajuan ilmu pengetahuan. Dalam konteks ini biasanya peneliti akan memajukan ilmu pengetahuannya yang dipermasalahkan dan akan menjadi penjelasan dalam penelitian berikutnya. Metode ini dimaksudkan untuk memecahkan masalah dengan menggambarkan objek/subjek sebagaimana adanya pada saat penelitian ini dilakukan. Bogdan dan Taylor (1949:4) mengatakan "Qualitative methodologies refer to research procedures which produce descriptive data". Artinya metodologi kualitatif mengacu pada prosedur penelitian yang menghasilkan data deskriptif. Adapun bentuk penelitiannya adalah studi kasus.

Agar permasalahan dalam penelitian ini dapat terjawab, maka diperlukan sumber data yang sesuai dengan kebutuhan, masalah, dan tujuan penelitian. Pemilihan sumber data disesuaikan dengan metode dan bentuk penelitian dan teknik pengumpulan data melalui observasi langsung, komunikasi langsung dan teknik dokumentasi.

Pengertian dari sumber data dikemukakan oleh Zuldafrial (2009:69), yang menyatakan bahwa Sumber data adalah subyek dari mana data diperoleh, apabila peneliti menggunakan wawancara dalam mengumpulkan datanya, maka sumber data disebut responden yaitu orang yang merespon atau menjawab pertanyaan-pertanyaan peneliti, baik pertanyaan tertulis maupun lisan, sedangkan datanya kata-kata lisan dan tulisan. Apabila peneliti menggunakan observasi, maka sumber datanya tindakan atau perilaku atau proses sesuatu. Sumber-sumber data dalam penelitian ini yaitu: 
1. Informan

Pada penelitian kualitatif dikenal adanya informan. Dalam penelitian ini informan sangat penting artinya sebagai individu yang memiliki informasi yang berhubungan dengan penelitian. Informan merupakan seseorang yang diwawancarai untuk mendapatkan keterangan dan data untuk keperluan informasi. Untuk itu dalam memilih informan peneliti harus pandai menentukan siapakah informan yang bisa dijadikan sumber data agar data yang didapat untuk penelitian dapat dipertanggung jawabkan. Informan dalam penelitian ini adalah seorang Guru Sejarah Sekolah Menengah Atas Negeri 2 Sekadau Kabupaten Sekadau dan Narasumber Kerajaan Sekadau.

2. Tempat dan Aktivitas

Tempat atau lokasi juga menentukan keberhasilan dari sebuah penelitian. Karena sumber data yang didapat dari tempat atau lokasi tersebut tentunya akan sangat mendukung kinerja peneliti. Adapun yang menjadi tempat atau lokasi dalam penelitian ini adalah Sekolah Menengah Atas Negeri 2 Sekadau Kabupaten Sekadau, di mana di sekolah ini akan diteliti apakah Kerajaaan Sekadau dapat dijadikan sumber belajar di sekolah ini.

3. Arsip dan Dokumen

Arsip dan dokumen merupakan suatu hal yang penting didalam penelitian karena biasanya arsip dan dokumen merupakan bahan tertulis yang sifatnya memberikan suatu bukti tentang suatu peristiwa atau kejadian. Arsip dan dokumen juga dapat mempermudah kerja peneliti karena dapat dijadikan sumber data. Menurut Gottschalk (2008:45-46), kata dokumen (dari kata docere, mengajar) mengandung arti sumber tertulis bagi informasi sejarah sebagai kebalikan daripada kesaksian lisan, artifact, peninggalan-peninggalan terlukis, dan petilasan-petilasan arkeologis. Adapun arsip dan dokumen yang menjadi sumber data dalam penelitian ini yaitu perangkat pembelajaran guru sejarah seperti Program Tahunan, Program Semester, Sila- bus, Rencana Pelaksanaan Pembelajaran (RPP), buku pelajaran sejarah, foto-foto dan benda-benda peninggalan Kerajaan Sekadau yang masih ada.

\section{Teknik Pengumpulan Data}

Teknik pengumpulan data yang digunakan dalam penelitian ini adalah sebagai berikut :

1. Teknik Observasi Langsung Teknik observasi langsung dilakukan melalui pengamatan dan pencatatan gejalagejala yang tampak pada objek penelitian secara sistematik yang langsung dilakukan di kelas pada saat proses belajar mengajar. Di sini peneliti akan mencatat data dari proses pembelajaran yang dilakukan oleh guru dan siswa. Apakah guru sudah memanfaatkan atau menggunakan Kerajaan Sekadau secara maksimal sebagai sumber belajar yang diharapkan bisa membuka wawasan siswa tentang Sejarah Lokal yang ada di sekitarnya.

2. Teknik Komunikasi Langsung Pada teknik komunikasi langsung ini dilakukan wawancara terhadap Guru sejarah kelas XI Sekolah Menengah Atas Negeri 2 Sekadau Kabupaten Sekadau. Wawancara dilakukan sebelum dan sesudah proses pembelajaran berlangsung. Selain itu peneliti juga akan mewawancarai seorang Narasumber mengenai Kerajaan Sekadau.

3. Teknik Dokumentasi

Teknik dokumentasi dilakukan dengan mengumpulkan foto-foto, arsip-arsip dari Kerajaan Sekadau, buku pelajaran sejarah, Program Tahunan, Program Semester, Silabus, Rencana Pelaksanaan Pembelajaran (RPP) dan lain-lain.

\section{Instrumen Penelitian}

Instrumen yang digunakan dalam pengumpulan data adalah sebagai berikut:

1. Panduan Observasi

Panduan observasi berbentuk daftar chek list yaitu daftar yang dibuat oleh peneliti yang disusun secara sistematis disertai gejala-gejala yang akan diamati yang berkaitan dengan tujuan penelitian. 
Dalam hal ini peneliti akan mengamati guru dan siswa pada saat proses pembelajaran berlangsung.

2. Panduan Wawancara

Panduan wawancara adalah bentuk komunikasi langsung antara dua orang atau lebih dengan alat pengumpul data nya berbentuk interview (wawancara). Interview dilakukan langsung peneliti kepada Guru sejarah kelas XI Sekolah Menengah Atas Negeri 2 Sekadau Kabupaten Sekadau dan juga seorang Narasumber Kerajaan Sekadau.

3. Dokumentasi

Didalam melaksanakan metode dokumentasi, peneliti menyelidiki benda-benda tertulis seperti buku-buku, majalah, peraturan-peraturan, notulen rapat, catan-catatan harian dan sebagainya. Berdasarkan pendapat di atas maka dalam penelitian ini peneliti menggunakan dokumentasi foto-foto, arsip-arsip dari Kerajaan Sekadau, benda-benda peninggalan Kerajaan Sekadau, buku pelajaran sejarah, Program Tahunan, Program Semester, Silabus, dan Rencana Pelaksanaan Pembelajaran (RPP).
Teknik cuplikan atau sampling yang digunakan dalam penelitian ini adalah purposive sampling dan bersifat snowball sampling. Hal ini bertujuan agar sumber data yang didapat dapat diuji kebenarannya.

\section{Teknik Pemeriksaan Keabsahan Data}

Data yang telah diperoleh belum tentu semuanya sesuai dengan kebenaran yang diinginkan oleh peneliti. Dengan demikian data yang telah diperoleh tentunya harus di periksa kembali agar tidak terjadi bias antara data dengan kenyataan yang ada di lapangan, sehingga cara yang dianggap tepat untuk memeriksa keabsahan data tersebut dengan teknik triangulasi yaitu teknik pengumpulan data yang bersifat menggabungkan dari berbagai teknik pengumpulan data dan sumber data yang telah ada. Penelitian ini menggunakan triangulasi data dan triangulasi metode. Triangulasi sumber (data) digunakan agar data yang diperoleh dari sumber yang satu bisa lebih teruji kebenarannya. Triangulasi sumber ditunjukkan oleh Bagan 1 berikut ini.

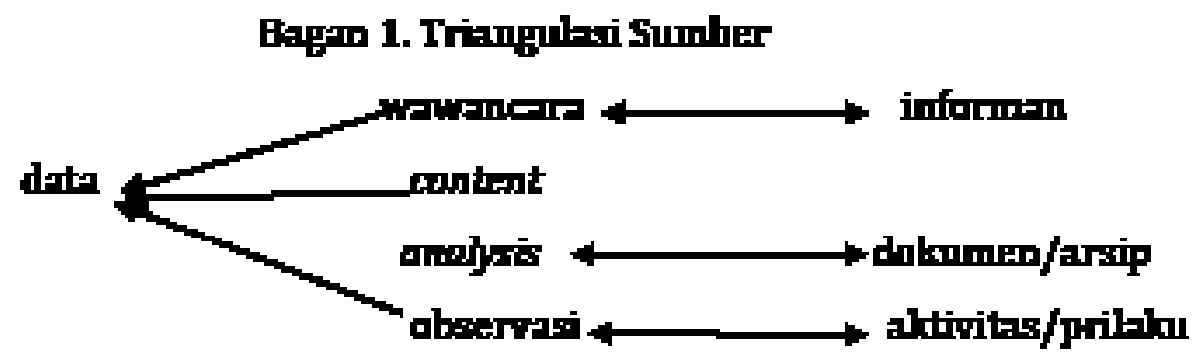

Sumber: Sutopo (2006:94)

Pada triangulasi sumber, peneliti melakukan wawancara mendalam, mengumpulkan dokumen-dokumen dan mengobservasi atau mengamati keadaan di lapangan.
Dalam trianggulasi metode, peneliti mengamati satu sumber data dapat menggunakan beberapa metode seperti metode wawancara, observasi dan dokumentasi sebagaimana ditunjukkan oleh Bagan 2. 


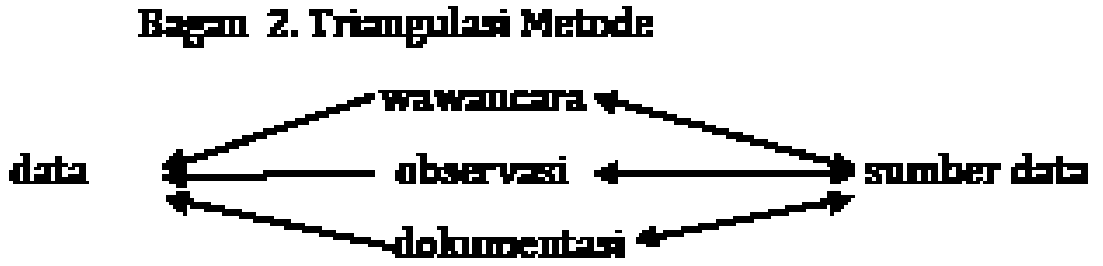

Sumber: Sutopo (2006:94)

Pada triangulasi metode ketika mengamati satu sumber, misalnya ketika mengumpulkan data dari guru, peneliti menggunakan beberapa metode seperti metode wawancara, observasi, dan dokumentasi.

\section{Teknik Analisis Data}

Aktivitas dalam analisis data, yaitu pengumpulan data, reduksi data, penyajian data dan penarikan kesimpulan atau verifikasi, seperti berikut ini:

1. Pengumpulan data

Data yang didapat dari catatan di lapangan masih bersifat kasar. Artinya ketika peneliti turun ke lapangan utuk mencari data yang berkaitan dengan penelitian tidak melihat apakah data itu sesuai atau tidak dengan yang akan diteliti nantinya, melainkan semua data yang diperoleh diambil. Sehingga dari hasil data yang diperoleh selama di lapangan harus di proses lagi dengan cara melakukan reduksi data, penyajian data, kemudian baru dapat disimpulkan.

2. Data Reduction (Reduksi Data)

Data yang diperoleh di lapangan jumlahnya cukup banyak, untuk itu maka perlu dicatat secara teliti dan rinci. Untuk itu segera dilakukan analisis data melalui reduksi data. Mereduksi data berarti merangkum, memilih hal-hal yang pokok, memfokuskan pada hal-hal yang penting, dicari tema dan polanya (Sugiyono, 2012:91).

3. Data Display (Penyajian Data)

Setelah data direduksi maka tahap selanjutnya adalah mendisplay data. Melalui penyajian data maka data yang diperoleh dapat terorganisasikan, tersusun dalam pola hubungan, sehingga akan mudah dipahami. Dalam penelitian kualitatif penyajian data bisa dilakukan dalam bentuk uraian singkat dan sejenisnya (Sugiyono, 2012:95).

4. Conclusion Drawing / verification Langkah selanjutnya adalah penarikan kesimpulan dan verifikasi. Kesimpulan awal yang dikemukakan masih bersifat sementara dan akan berubah bila tidak ditemukan bukti-bukti yang kuat yang mendukung pada tahap pengumpulan data berikutnya (Sugiyono, 2012:99).

\section{HASIL PENELITIAN DAN PEMBAHASAN}

Proses Pembelajaran Sejarah Pada Materi Masuk dan Berkembangnya Agama Islam di Indonesia

Proses pembelajaran sejarah di kelas XI berlangsung dengan baik, siswa memperhatikan materi yang disampaikan oleh guru. ketika pembelajaran berlangsung siswa tidak hanya memperhatikan materi tetapi juga berperan aktif seperti mengajukan beberapa pertanyaan seputar materi yang belum bisa mereka pahami secara mendalam. Pertanyaan yang diajukan oleh siswa contohnya adalah bagaimana proses awal masuknya Islam ke daerah Sekadau, apakah ada perlawanan dari masyarakat setempat yang telah menganut kepercayaan animisme, apa bukti masuknya Islam ke daerah Sekadau dan lain sebagainya. Dengan beberapa pertanyaan yang diajukan oleh siswa guru kemudian 
menjelaskan satu persatu dari pertanyaan tersebut dan secara detail sehingga siswa dapat memahami materi yang disampaikan oleh guru. Interaksi yang terjadi di dalam kelas menunjukan suatu umpan balik yang dapat diterima oleh siswa dengan penjelasan-penjelasan yang telah disampaikan oleh guru tersebut. Pelajaran sejarah dapat memberikan pengalaman yang sangat bermanfaat bagi siswa kelak dikemudian hari. Misalnya dengan diceritakannya kejadian-kejadian yang terjadi pada masa lampau siswa diarahkan untuk dapat mengambil manfaat dari kejadian tersebut untuk kehidupan di masa kini dan masa mendatang agar kejadian yang tidak baik yang pernah terjadi pada masa lampau tidak terulang kembali di masa yang akan datang. Hal ini sejalan dengan apa yang dikatakan oleh Isjoni (2007:86) bahwa materi pembelajaran pendidikan sejarah di sekolah harus mampu memberikan pengalaman kepada siswa menarik pelajaran dari peristiwa sejarah, melihat relevansinya dengan peristiwa atau kehidupan masa kini dan dikembangkan untuk kehidupan masa yang akan datang.

\section{Penggunaan Kerajaan Sekadau Oleh Guru Sejarah Sebagai Sumber Belajar Sejarah}

Keberadaan Kerajaan Sekadau tidak akan bisa dimanfaatkan sebagai sumber belajar apabila guru tidak memiliki langkah-langkah atau cara-cara tertentu dalam penggunaannya. Berdasarkan hasil observasi, wawancara dan dokumen-dokumen yang didapatkan di lapangan, dalam rangka menggunakan Kerajaan Sekadau sebagai sumber belajar di SMA Negeri 2 Sekadau guru terlebih dahulu melakukan persiapan-persiapan pembuatan perangkat mengajar mulai dari Program Tahunan, Program Semester, Silabus dan RPP. Kemudian guru menjelaskan tentang perkembangan Kerajaan dari masa ke masa khususnya pada masa masuk dan berkembangnya agama Islam di Indonesia.

Kerajaan Sekadau berdiri sekitar abad ke 13 yaitu sekitar tahun 1400 masehi. Dimana Raja yang memimpin pada saat itu bernama Pangeran Engkong, setelah Pangeran Engkong wafat digantikanlah oleh anaknya yang bernama Pangeran Kadar, Pangeran Kadar kemudian digantikan lagi oleh Pangeran Suma. Nantinya anak dari Pangeran Suma yang bernama Sultan Anom ini lah yang terkenal dengan mulai masuknya agama Islam ke daerah Sekadau. Perkembangan Kerajaan Sekadau selanjutnya, diawali dengan perjalanan Sultan Anom oleh orang tuanya untuk mendatangi Mempawah guna memperdalam pengetahuannya, terutama dalam bidang agama Islam (Dinas Kebudayaan dan Pariwisata Sekadau, 2006:3).

Setelah bertahun-tahun lamanya Surau Kerajaan berdiri, karena sering tergenang air pada saat banjir karena memang terletak tepat ditepi sungai Sekadau, maka pada tahun 1804 didirikan Masjid Al Taqwa yang bertempat tidak jauh dari surau pertama didirikan. Motif bangunan masjid menyerupai Masjid Demak yang didirikan oleh Sunan Kalijaga.

Dilihat dari bangunan Masjid yang dirancang sedemikian rupa dengan bagian-bagian yang penuh arti penting dalam ajaran agama Islam, menunjukan bahwa begitu pesatnya agama Islam yang berkembang pada masa itu, ditambah lagi dengan hubungan dengan kerajaan-kerajaan lainnya yang sudah memeluk agama Islam yang ada di Kalimantan Barat, salah satunya hubungan baik dengan Kerajaan Mempawah yang pada saat itu sudah menganut agama Islam.

Sampai saat ini Masjid Jami' At Taqwa masih berdiri tegak dengan perawatan dari masyarakat setempat dan keturunan Raja-Raja Sekadau selanjutnya, walaupun Kerajaan Sekadau telah melebur menjadi satu dengan Negara Kesatuan Republik Indonesia (NKRI) pada bulan Juni tahun 1952. Masjid ini dapat menjadi warisan budaya di daerah Sekadau yang sangat berarti bagi kelangsungan kerukunan hidup masyarakat di daerah Sekadau.

Setelah menjelaskan materi yang dihubungkan dengan Kerajaan Sekadau, guru melakukan evaluasi-evaluasi untuk mengetahui tingkat pemahaman siswa tentang Kerajaan Sekadau. Evaluasi berupa tes tertulis yang mana pertanyaan-pertanyaannya mengenai materi yang telah diajarkan.

Disamping memanfaatkan sumber be- 
lajar yang ada, guru dituntut untuk mencari dan merencanakan sumber belajar lainnya baik dari rancangan sendiri ataupun sumber yang sudah tersedia di sekitar lingkungan sekolah dan masyarakat. Strategi atau peran guru dalam menyampaikan sejarah Kerajaan Sekadau sebagai sumber belajar sangatlah penting. Dengan mengemas metode yang dapat menarik minat siswa dalam pembelajaran sejarah dapat menentukan berhasil atau tidaknya suatu pembelajaran. Apabila sang guru tidak dapat menyampaikan materi tersebut dengan baik maka dipastikan siswa akan cepat jenuh dengan proses pembelajaran yang berlangsung. Isjoni (2007:15) menyatakan bahwa salah satu cara membuat pembelajaran sejarah menjadi menarik dimata siswa ialah dengan mengajak siswa untuk mempelajari kondisi-kondisi nyata di sekitar siswa. Dalam menyampaikan materi masuk dan berkembangnya agama Islam di daerah Sekadau guru menyinggung tentang awal mula berdirinya Kerajaan Sekadau tersebut.

\section{Kerajaan Sekadau Sebagai Sumber Be- lajar Materi Masuk dan Berkembangnya Agama Islam di Indonesia.}

Keberadaan Kerajaan Sekadau di Kabupaten Sekadau Kalimantan Barat, hanya akan menjadi sejarah masa lampau apabila tidak digunakan sebagai bentuk peninggalan sejarah yang memiliki nilai sejarah yang tinggi. Untuk itu peran semua pihak untuk memaknai peninggalan sejarah yang ada di Kabupaten Sekadau sangat dibutuhkan, salah satunya adalah keberadaan Kerajaan Sekadau di Kabupaten Sekadau. Salah satu pihak yang memiliki posisi yang strategis dalam rangka memberikan pemahaman tentang pentingnya memahami peninggalan sejarah adalah instansi pendidikan.

Seperti diketahui jantung pendidikan adalah proses pembelajaran yang terjadi di sekolah. Acuan dari proses pembelajaran itu sendiri adalah kurikulum. Kurikulum Tingkat Satuan Pendidikan (KTSP) memberikan peluang kepada sekolah untuk mengembangkan, mengkreasikan, proses pembelajaran di sekolah masing-masing. Mulai dari strategi pembelajaran, model, metode, termasuk pemanfaatan sumber bahan ajar.

Sejalan dengan tujuan KTSP di atas, maka pelajaran sejarah juga diberi kesempatan untuk mengembangkan model, strategi, metode, termasuk sumber belajar sejarah. Sumber belajar sejarah dapat menggunakan sumber belajar yang ada di lingkungan tempat tinggal siswa, ini juga dapat membantu mengurangi unsur verbalitas dalam pembelajaran sejarah. Hal ini sesuai dengan pendapat Kochar (2008:160) yang menyatakan bahwa sumber pembelajaran adalah sarana pembelajaran dan pengajaran yang sangat penting. Sudah menjadi keharusan bagi guru untuk mengeksplorasi berbagai macam sumber untuk mendapatkan alat bantu yang tepat untuk mengajar dari melengkapi apa yang sudah disediakan dalam buku cetak, untuk menambah informasi, untuk memperluas konsep dan untuk membangkitkan minat peserta didik.

Kabupaten Sekadau memiliki banyak sumber belajar sejarah yang dapat digunakan salah satunya adalah Kerajaan Sekadau. Kerajaan Sekadau dapat dijadikan sebagai sumber belajar pada materi masuk dan berkembangnya agama Islam di Indonesia di kelas XI. Ketika Islam mulai masuk dan berkembang di Indonesia, daerah Sekadau yang pada masa itu masih berbentuk kerajaan tidak luput dari pengaruh Islam tersebut. Hal ini juga dapat terlihat dari suku melayu yang sebagian besar telah menganut agama Islam saat ini di daerah Sekadau. Kisah tentang Kerajaan Sekadau ini tentunya memberikan banyak pelajaran yang berharga bagi siswa karena mereka dapat mengetahui proses masuknya agama Islam di daerah yang mereka tempati saat ini. Jadi mereka tidak hanya tahu bahwa agama Islam hanya berkembang di daerah Jawa tetapi juga sampai kedaerah pelosokpelosok Indonesia yang ditandai dengan berbagai peristiwa yang terjadi. Bukti masuk dan berkembangnya agama Islam di Indonesia hingga saat ini masih dapat dilihat salah satunya yaitu Masjid At-Taqwa yang masih berdiri kokoh yang teletak di Desa Mungguk. Adapun pemanfaatan Kerajaan Sekadau sebagai sumber belajar ini untuk memudahkan siswa 
dalam memahami jenis Sejarah Lokal dan jenis sejarah kebudayaan dengan memberikan contoh yang konkret yang ada di sekitar mereka. Hal ini sejalan dengan Isjoni (2007:42) yang menyatakan bahwa pendekatan pembelajaran dalam bentuk menghubungkan materi dalam buku-buku teks sejarah dengan lingkungan sekitar siswa dan penuh makna, sehingga dapat memberikan kontribusi penyelesaian masalah sekarang.

\section{SIMPULAN}

Berdasarkan hasil penelitian dan pembahasan secara umum dapat ditarik kesimpulan bahwa Kerajaan Sekadau dapat dikembangkan sebagai sumber belajar sejarah pada siswa kelas XI Sekolah Menengah Atas Negeri 2 Sekadau. Kemudian secara khusus kesimpulan tersebut seperti dijelaskan sebagai berikut:

1. Proses pembelajaran sejarah pada materi masuk dan berkembangnya agama Islam di Indonesia.

Proses penyampaian materi pada saat masuk dan berkembangnya agama Islam di Indonesia pada siswa kelas XI berjalan dengan baik dan efisien. Pada saat penyampaian materi guru menggunakan metode ceramah bervariasi dan diselingi dengan tanya jawab, siswa terlihat sangat antusias dalam bertanya dan mengemukakan pendapatnya. Sehingga tujuan utama yang hendak dicapai dalam RPP dan Silabus dapat tersampaikan dengan baik dan lancar.

Seperti halnya Kerajaan Sekadau yang dapat dijadikan sumber belajar sejarah pada saat masuknya Islam di Indonesia, dengan menyisipkan kisah Kerajaan Sekadau dan menunjukan situs-situs bersejarah yang masih ada seperti keraton, masjid, meriam, makam raja-raja dan lainnya diharapkan dapat menarik minat dan merangsang pikiran siswa untuk lebih jauh mengenal daerahnya sendiri, kemudian menggali lebih dalam potensi-potensi yang ada di sekitarnya juga menemukan lebih banyak lagi sumbersumber belajar lainnya yang dapat digunakan dalam proses pembelajaran di sekolah.

2. Guru menggunakan Kerajaan Sekadau sebagai sumber belajar sejarah siswa kelas
XI Sekolah Menengah Atas Negeri 2 Sekadau.

Strategi guru dalam menyampaikan materi masuk dan berkembangnya agama Islam dengan menyisipkan kisah Kerajaan Sekadau dapat dilaksanakan dengan baik. Dengan mengemas model pembelajaran yang menarik diharapkan dapat menarik minat siswa dalam mempelajari dan memperdalam pengetahuan tentang kebudayaan yang ada di sekeliling mereka. Dengan begitu tujuan guru yang tidak hanya mengajar tetapi juga mendidik siswanya dalam meningkatkan kepedulian akan lingkungan dan alam akan terlaksana. Dengan menyisipkan kisah Kerajaan Sekadau dalam materi yang sesuai maka dapat menumbuhkan motivasi siswa untuk terus memperluas wawasan dan kesadaran sejarah yang sudah mulai ditinggalkan akibat kemajuan zaman yang begitu pesat. Peran guru sebagai motivator di lingkungan sekolah sangatlah berarti bagi perkembangan siswa dalam memperluas wawasan tersebut. 3. Kerajaan Sekadau sebagai sumber belajar sejarah materi masuk dan berkembangnya agama Islam di Indonesia pada siswa kelas XI Sekolah Menengah Atas Negeri 2 Sekadau.

Selain di sekolah, sumber belajar juga bisa di dapat di lingkungan atau tempat tinggal sekitar kita. Keadaan yang ada di lingkungan sekitar dapat dijadikan sumber belajar yang konkret bagi siswa. Disamping memberikan teori-teori yang ada di buku pelajaran kepada siswa, dapat pula ditunjukan benda-benda yang ada di sekitar siswa sebagai contohnya. Dengan begitu siswa akan lebih cepat paham dengan apa yang disampaikan dalam materi, juga akan lebih mudah tersimpan di dalam memorinya dan yang tidak kalah penting adalah dapat memberikan pengalaman pada setiap proses pembelajaran berlangsung.

\section{UCAPAN TERIMA KASIH}

Dalam kesempatan ini penulis mengucapkan terima kasih kepada berbagai pihak yang telah membantu dalam pelaksanaan penelitian ini khususnya SMA Negeri 1 Nanga Taman. Penulis juga mengucapkan terima kasih kepada dewan redaksi Jurnal Socia atas 
kesempatan yang diberikan sehingga paper ini dapat diterbitkan pada Jurnal Socia edisi September 2015 .

\section{DAFTAR PUSTAKA}

Aman. 2011. Model Evaluasi Pembelajaran Sejarah. Yogyakarta: Ombak.

Bogdan, R \& Taylor, S. (1949). Introduction to Qualitative Research Methods. United States of America: Jhon Wilye \& Sons.

Darmadi, H. 2011. Metode Penelitian Pendidikan. Bandung: Alfabeta.

Gottschalk, L. 2008. Mengerti Sejarah. Jakarta: UI Press

Isjoni. 2007. Pembelajaran Sejarah Pada Satuan Pendidikan. Bandung: Alfabeta.

Kochar, S.K. 2008. Pembelajaran Sejarah. Jakarta: PT. Grasindo.
Mason J. E. dan Bramble, W.J. 1998. Kualitatif Research for Education. London: Library of Congress Cataloging in Publication Data.

Saad, M. 2009, Dari Betang Panjang Menuju Sekadau Maju dan Mandiri. Penerbit Kerjasama Pemerintah Kabupaten Sekadau dan Yayasan Insan Kampus Pontianak.

Sugiyono. 2012. Metode Penelitian Kualitatif. Bandung: Alfabeta.

Sutopo. 2006. H.B. (2006). Metode Penelitian Kualitatif. Surakarta : Universitas Sebelas Maret.

Usman, S. 2011. Sejarah Kontemporer Kalimantan Barat Sedjak Tempo Doeloe. Koleksi Kalangan Sendiri.

Zuldafrial. 2009. Pendekatan Penelitian dan Teknik Penulisan Karya Ilmiah. Pontianak: Pustaka Abuya. 